\title{
PENERAPAN GEOGEBRA BERBASIS ELITA (E-LEARNING UNTIDAR) DI PERGURUAN TINGGI
}

\author{
Megita Dwi Pamungkas ${ }^{1)}$, Zuida Ratih Hendrastuti ${ }^{2)}$ \\ ${ }^{1)}$ Universitas Tidar, Jalan Kapten Suparman nomor 39, Magelang \\ ${ }^{1)}$ megitadwip@untidar.ac.id; ${ }^{2}$ zuidaratihh@untidar.ac.id
}

Received : 05/11/2019

Accepted : 29/01/2020

Published : 31/01/2020

\begin{abstract}
Students of math teacher candidates often find geometric concepts that are difficult to understand. This leads to a decreased interest in geometry. The purpose of this research is to decrypt the impact of using the the GeoGebrabased ELITA on student learning achievement of mathematical teachers in field geometry. A total of 56 students were selected from the University of Tidar's Mathematics Education Study Program, a State university located in Magelang, Central Java, Indonesia. The experimental group (35) was taught about painting special lines on triangles using GeoGebra while the control group (36) was taught using conventional teaching methods. At the end of the study, student learning achievement was measured using posttest. The results showed that GeoGebra based ELITA is an effective tool for teaching and learning field geometry in college.
\end{abstract}

Keywords: GeoGebra, ELITA, geometri

\begin{abstract}
Abstrak
Mahasiswa calon guru matematika sering menemukan konsep geometris yang sulit untuk dipahami. Hal ini menyebabkan penurunan minat dalam geometri. Tujuan dari penelitian ini adalah untuk mendekripsikan dampak menggunakan GeoGebra berbasis ELITA pada prestasi belajar mahasiswa calon guru matematika di mata kuliah geometri bidang. Sebanyak 56 siswa dipilih dari program studi Pendidikan Matematika Universitas Tidar, sebuah universitas negeri yang terletak di Magelang, Jawa Tengah, Indonesia. Kelompok eksperimen (35) diajarkan tentang melukis garis-garis istimewa pada segitiga menggunakan GeoGebra sementara kelompok kontrol (36) diajarkan menggunakan metode pengajaran konvensional. Pada akhir penelitian, prestasi belajar mahasiswa diukur dengan menggunakan post-test. Hasil penelitian menunjukkan bahwa GeoGebra berbasis ELITA adalah alat yang efektif untuk mengajar dan belajar geometri bidang di perguruan tinggi.
\end{abstract}

Kata Kunci: GeoGebra, ELITA, geometri

\section{Pendahuluan}

Geometri merupakan salah satu cabang ilmu matematika. Geometri adalah studi tentang bentuk dan ruang (Guven \& Kosa, 2008). Ini memungkinkan seseorang untuk memahami dunia dengan membandingkan bentuk, objek dan koneksinya (Gunhan, 2014). Memahami geometri itu penting untuk diri sendiri dan untuk memahami bidang lain matematika. Ini memberikan kontribusi untuk penalaran logis dan deduktif tentang objek spasial dan hubungan (Alqahtani \& Powell, 2016). Karena itu, pemahaman konsep geometri harus dikembangkan secara efektif dalam pembelajaran matematika. 
Sebagaimana objek matematika lainnya, objek geometri juga bersifat abstrak. Hal ini membuat banyak mahasiswa calon guru matematika akan mengalami kesulitan dalam mempelajarinya. Kenyataan yang demikian mendorong perlunya media pembelajaran yang dapat memberikan gambaran visual dalam mempelajari objek-objek geometri yang bersifat abstrak tersebut. Meskipun visualisasi adalah elemen penting untuk pengajaran geometri, belum ada alat yang efektif untuk mengajarkan topik-topik geometri ini.

Baru-baru ini, tidak dapat dihindari bahwa teknologi menjadi pertimbangan utama di Indonesia mengembangkan setiap aspek kehidupan manusia, termasuk bagaimana hal ini dapat membuat akselerasi besar dalam menyiapkan lingkungan belajar mahasiswa yang lebih baik. Teknologi bisa memberikan kesempatan yang bagus bagi mahasiswa untuk melakukan eksplorasi mendalam tentang pemahaman mereka tentang suatu konsep. Karena pentingnya teknologi ini dalam pengajaran matematika, Dewan Guru Nasional Matematika (NCTM: 2000) menyerukan untuk membangun kebijakan pendidikan yang memanfaatkan teknologi dalam pengajaran matematika penggunaan perangkat pintar dan aplikasi yang berbeda. Dengan demikian, mahasiswa menerima program pengajaran di matematika secara luas, karena kemampuan teknologi untuk mempromosikan pembelajaran mahasiswa melalui perwujudan ide matematika dalam bentuk yang terlihat.

Ada berbagai jenis perangkat lunak komersial yang tersedia untuk pengajaran dan pembelajaran Matematika di pasar terbuka. Misalnya Geometer's Sketchpad, Derive, Cabri, Matlab, Autograph, dan lainnya. Perangkat lunak matematika ini telah digunakan di sekolah dan juga universitas di seluruh dunia. Dalam studi ini, kami telah memilih GeoGebra sebagai alat visualisasi dalam pengajaran dan perkuliahan geometri bidang.

Penelitian ini dilakukan dengan mempertimbangkan perlunya media pembelajaran geometri yang efektif untuk visualisasi siswa. Sebagai pertimbangan utama dan fakta bahwa lebih dari 70\% mahasiswa sarjana pendidikan matematika Universitas Tidar memiliki milai harian di bawah 70 selama pembelajaran geometri bidang. Dalam mengakomodasi kebutuhan peningkatan mahasiswa sarjana dalam memahami konsep tertentu dalam geometri, dan fakta bahwa GeoGebra terbukti dapat membantu siswa memahami lebih banyak tentang geometri. Penelitian ini dilakukan dengan memperhatikan bagaimana mengintegrasikan GeoGebra berbasis ELITA pada geometri bidang di universitas. Namun, peneliti membatasi pokok bahasan hanya melukis dan menggambar garis-garis istimewa pada segitiga.

Geometri bidang adalah salah satu mata kuliah yang ditawarkan pada semester 1 di program studi Pendidikan Matematika, Universitas Tidar. Menurut kurikulum Program Studi 
Pendidikan Matematika, mata kuliah ini memuat bahasan tentang tentang konsep dan obyek geometri, kekongruenan, kesebangunan, kesejajaran, segitiga, segiempat dan berbagai karakteristiknya, segi banyak, lingkaran, keliling dan luas daerah bangun datar.

GeoGebra adalah perangkat lunak dinamis dan gratis untuk pengajaran dan pembelajaran Matematika yang menawarkan fitur geometri dan aljabar dalam lingkungan perangkat lunak yang sepenuhnya terhubung. Ini dirancang untuk menggabungkan fitur perangkat lunak geometri dinamis dan sistem aljabar komputer dalam sistem tunggal, terintegrasi, dan mudah digunakan untuk mengajar dan belajar matematika, (Hohenwarter, Jarvis, \& Lavicza, 2009). GeoGebra didasarkan pada kriteria ilmiah matematika. GeoGebra dirancang oleh Markus Hohentwrter dan sekarang telah diterjemahkan ke 40 bahasa. Pengguna di seluruh dunia dapat dengan bebas mengunduh software ini dari resmi Situs web GeoGebra di http://www.geogebra.org.

Ada tujuh menu dalam GeoGebra seperti File, Edit, View, Options, Tools, Window, dan Help. GeoGebra juga memiliki beberapa alat untuk memvisualisasikan objek dua dimensi, seperti titik, garis, garis tegak lurus, poligon, lingkaran, elips, sudut, refleksi tentang garis, slider, dan memindahkan tampilan grafik. Menu tersebut membantu kita memvisualisasikan objek Geometri sesuai dengan tujuan kita.

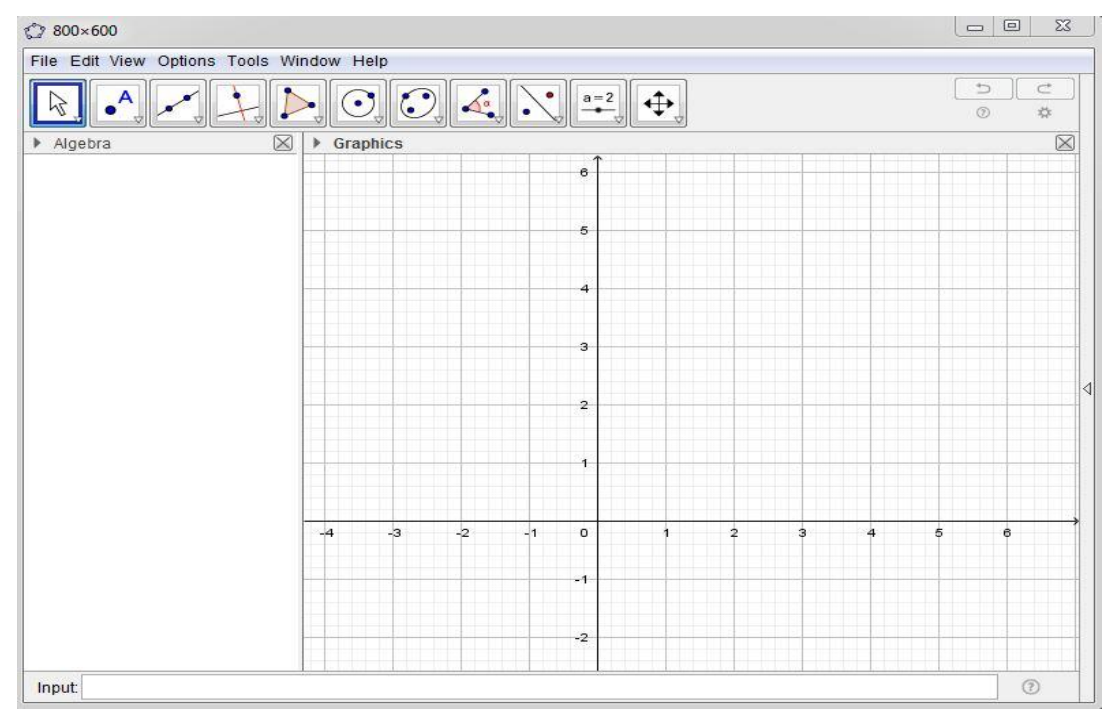

Gambar 1. Gambar Tampilan Awal GeoGebra

Selain itu, penerapan GeoGebra juga diintegrasikan dengan ELITA (E-learning Universitas Tidar). ELITA (E-learning Untidar) merupakan platform pembelajaran berbasis Moodle (Modular Object-Oriented Dynamic Learning Environment) yang dirancang untuk memberikan layanan pembelajaran daring bagi Dosen dan Mahasiswa dengan satu sistem yang kuat, aman dan terintegrasi untuk menciptakan lingkungan belajar daring yang dapat 
dipersonalisasi. ELITA juga sudah terintegrasi dengan SIMOKUL (Sistem Monitoring Kuliah) dan SPADA Indonesia dari Ristekdikti.

\section{Metode Penelitian}

Penelitian ini merupakan penelitian dengan desain quasi-experiment yang dibagi menjadi kelompok eksperimen dan kelompok kontrol. Tujuan dari penelitian ini adalah untuk menguji dampak penggunaan GeoGebra berbasis ELITA pada prestasi matematika siswa calon guru matematika dalam perkuliahan geometri bidang. Perbedaan antara pretest dan postest menentukan apakah GeoGebra berbasis ELITA mempengaruhi prestasi mahasiswa dalam melukis garis-garis istimewa pada segitiga.

Penelitian ini dilakukan terhadap 56 mahasiswa Program Studi Pendidikan Matematika semester 2 di Universitas Tidar di Magelang. Pengambilan sampel dilakukan dengan purposive sampling berdasarkan dua kelompok: kelompok eksperimen $(\mathrm{n}=27)$ diajarkan menggunakan GeoGebra berbasis ELITA, kelompok kontrol $(n=29)$ diajarkan menggunakan metode konvensional. Instrumen yang digunakan pada penelitian ini adalah postest prestasi mahasiswa dan kuesioner. Soal postest digunakan untuk membandingkan dan mengetahui perbedaan hasil perlakuan yang diberikan.

Tabel 1. Prosedur Penelitian

\begin{tabular}{|c|c|c|}
\hline & Kelompok Eksperimen & Kelompok Kontrol \\
\hline Fase I & Pembelajaran GeoGebra + ELITA & Pembelajaran Konvesional \\
\hline Fase II & Postest & Postest \\
\hline Fase III & Memberi kuesioner & - \\
\hline
\end{tabular}

Postest prestasi terdiri dari enam uraian dengan satu soal materi lukisan garis-garis istimewa pada segitiga. Postest ini diberikan kepada kelompok eksperimen dan kelompok kontrol. Postest prestasi digunakan untuk mengukur prestasi mahasiswa setelah melakukan perkuliahan menggunakan GeoGebra berbasis ELITA. Validitas tes diverifikasi dengan menghadirkan ahli yang diminta untuk memberikan pandangan dan saran mereka terhadap instrumen yang dibuat. Postest ini reliable dengan $r=0.83(\mathrm{p}<0.05)$.

Kemudian, pada kelompok eksperimen diberikan kuesioner tentang refleksi mahasiswa selama menggunakan GeoGebra berbasis ELITA pada perkuliahan Geometri bidang. kuesioner ini terdiri dari sembilan item dengan skala Likert 1-sangat tidak setuju, 2tidak setuju, 3-cukup setuju, 4-setuju, dan 5-sangat setuju. Kuesioner ini reliable dengan a = 0.86 dengan kriteria konsisten baik. 


\section{Hasil dan Pembahasan}

Dalam penelitian ini, pengaruh integrasi GeoGebra berbasis ELITA dalam geometri bidang telah diteliti dengan menggunakan rancangan kuasi-eksperimental. Hasilnya menunjukkan bahwa ada perbedaan yang signifikan antara pencapaian kelompok kontrol, yang diajarkan oleh metode pengajaran konvensional, dan kelompok eksperimental yang diajarkan menggunakan GeoGebra berbasis ELITA.

Tabel berikut mengilustrasikan kelompok kontrol rata-rata dengan pembelajaran konvensional dan kelompok eksperimental yang diajarkan dengan GeoGebra. Hasil uji independen t-tes membandingkan hasil dari posttest kedua kelompok menunjukkan bahwa ada perbedaan yang signifikan antara skor rata-rata kelompok kontrol $(\mathrm{M}=72,04)$ dibandingkan dengan kelompok eksperimental $(\mathrm{M}=83,32, \mathrm{p}=0,000<0,05)$. Perbedaan antara rata-ratanya adalah 11,28 dengan skor maksimum 100. Hasil penelitian dapat dilihat pada Tabel 2 berikut ini.

Tabel 2. Hasil Independent t-test Kelompok Kontrol dan Eksperimen

\begin{tabular}{ccccccc}
\hline Kelompok & $\mathrm{N}$ & Mean & Std Deviasi & $\mathrm{t}$ & $\mathrm{df}$ & Sig. (2-tailed) \\
\hline Kontrol & 36 & 72.04 & 7.35132 & -8.204 & 69 & 0.000 \\
Eksperimen & 35 & 83.32 & 5.87912 & & & \\
\hline
\end{tabular}

Temuan ini menunjukkan bahwa mahasiswa calon guru matematika yang menggunakan GeoGebra berbasis ELITA dalam geometri mereka yang antusias dalam prestasi belajar matematika daripada mahasiswa dengan pembelajaran konvensional. Hal ini menunjukkan bahwa perangkat lunak GeoGebra berbasis ELITA dapat meningkatkan prestasi mahasiswa calon guru matematika.

Hasil penelitian ini selaras dengan penelitian yang dilakukan oleh Kllogjeri P \& Shyti $\underline{\text { B (2010) }}$ yang menyimpulkan bahwa GeoGebra mendorong siswa untuk berbagi pengetahuan dan kreativitas mereka dalam matematika. Selain itu, siswa dari semua tingkat pengetahuan dapat mendorong Matematika dengan menggunakan GeoGebra (Mejerek: 2014). Mahmudi (2010) menyatakan bahwa dengan tampilan yang variatif dan menarik, GeoGebra dapat mempermudah dalam memanipulasi berbagai objek geometri sehingga dapat meningkatkan minat siswa dalam pembelajaran geometri. Berikut ini beberapa hasil pekerjaan mahasiswa yang menggunakan GeoGebra berbasis ELITA. 


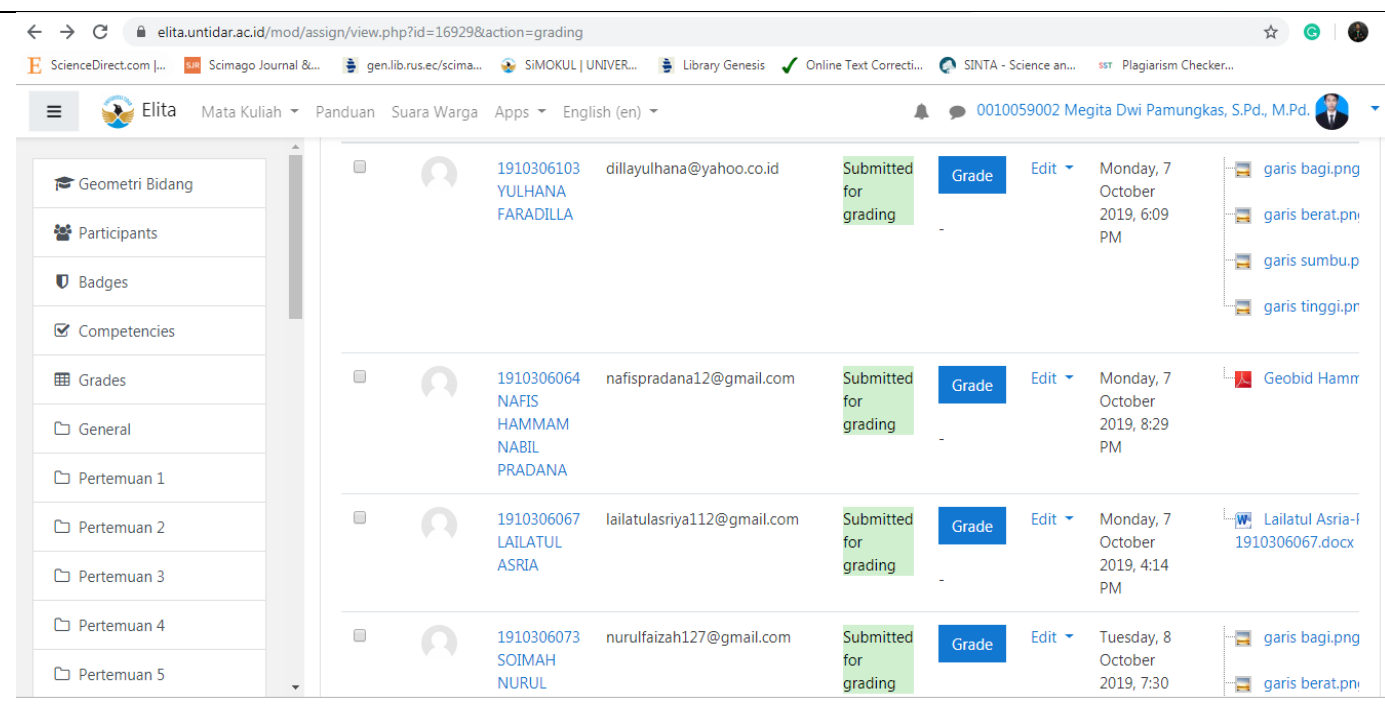

Gambar 2. Tampilan Tugas Mahasiswa melalui ELITA

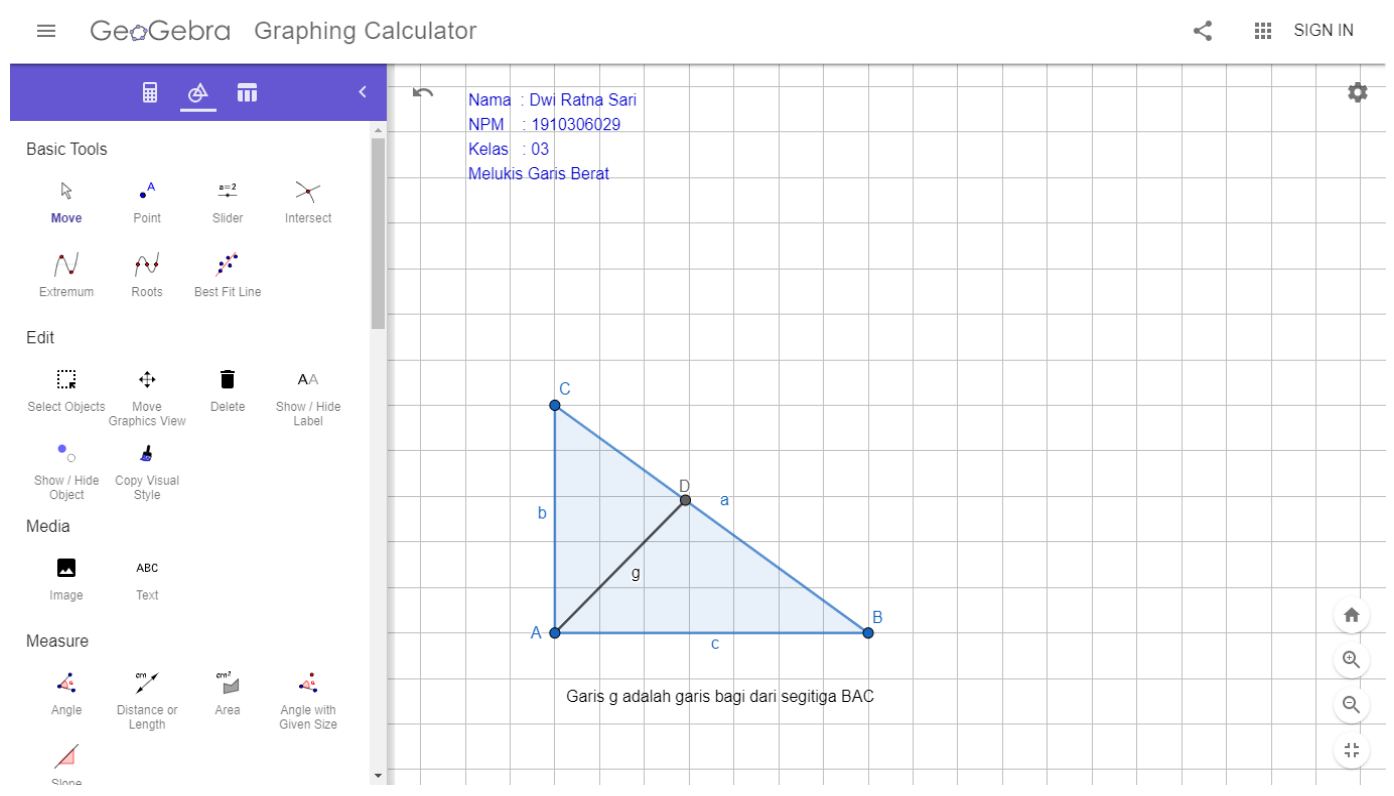

Gambar 3. Lukisan Garis Bagi Menggunakan GeoGebra

Hasil penelitian ini juga selaras dengan penelitian Saha, Ayub dan Tarmizi (2010) melakukan penelitian yang bertujuan mengidentifikasi dampak dari penggunaan GeoGebra pada pengajaran geometri koordinat pada sekelompok siswa sekolah menengah. Hasilnya menunjukkan perbedaan yang signifikan secara statistik antara rata-rata posttest dari kedua kelompok dalam yang mengunggulkan Kelompok GeoGebra. Emaikwu, Lji \& Abari (2015) menunjukkan bahwa penggunaan GeoGebra membantu siswa membangun pengetahuan baru dan menghubungkannya dengan pengetahuan sebelumnya, yang cukup konsisten dengan pendekatan pembelajaran yang konstruktif.

Selanjutnya, berdasarkan kuesioner yang memiliki rata-rata terendah adalah item yang menyatakan bahwa Saya percaya diri ketika pembelajaran menggunakan GeoGebra berbasis ELITA yaitu 3,89. Sedangkan nilai tertinggi adalah 4,3, itu diperoleh untuk item kedua 
"GeoGebra dapat membantu mengubah pembelajaran Geometri". Berdasarkan Tabel 3, berarti keseluruhan adalah 4.098. Ini menunjukkan seluruh mahasiswa setuju dengan pernyataan positif tentang GeoGebra berbasis ELITA. Siswa juga menemukan bahwa GeoGebra berbasis ELITA juga dapat memberikan kesan yang baik ketika belajar geometri

Tabel 3. Rata-rata Kuesioner Penggunaan GeoGebra berbasis ELITA

\begin{tabular}{clccc}
\hline No. & \multicolumn{1}{c}{ Item } & $\begin{array}{c}\text { Minimum } \\
\text { score }\end{array}$ & $\begin{array}{c}\text { Maximum } \\
\text { score }\end{array}$ & Mean \\
\hline 1 & 3 & 5 & 4,11 \\
2 & $\begin{array}{l}\text { GeoGebra membantu mempelajari } \\
\text { Geometri Bidang } \\
\text { GeoGebra membantu mengubah } \\
\text { pembelajaran geometri }\end{array}$ & 3 & 5 & 4,3 \\
3 & $\begin{array}{l}\text { Saya senang jika dosen menggunakan } \\
\text { GeoGebra berbasis ELITA }\end{array}$ & 3 & 5 & 4,19 \\
4 & $\begin{array}{l}\text { Saya percaya diri ketika pembelajaran } \\
\text { menggunakan GeoGebra berbasis ELITA }\end{array}$ & 3 & 5 & 3,89 \\
5 & $\begin{array}{l}\text { Saya dapat berpikir kreatif dan kritis } \\
\text { ketika menggunakan GeoGebra berbasis } \\
\text { ELITA } \\
\text { Rata-rata keseluruhan }\end{array}$ & 3 & 5 & 4 \\
\hline
\end{tabular}

Dari hasil ini dapat disimpulkan bahwa penggunaan Geogebra berbasis ELITA dapat meningkatkan eksplorasi, motivasi, dan minat mahasiswa calon guru dalam belajar matematika, terutama belajar geometri Bidang

\section{Kesimpulan}

Pembelajaran dan pengajaran geometri tidak harus difokuskan pada teori tetapi juga beragam pendekatan yang melibatkan penggunaan alat bantu pengajaran. Alat bantu pengajaran ini terbukti membantu merangsang minat mahasiswa dalam perkuliahan geometri bidang. Software matematika yang tersedia di pasar atau bahkan online telah memfasilitasi tugas pendidik untuk memberikan pengetahuan manfaat untuk para siswa.

Secara sangat meyakinkan, penelitian ini menunjukkan bahwa perangkat lunak GeoGebra berbasis ELITA memiliki dampak positif pada prestasi mahasiswa pada perkuliahan geometri bidang materi melukis garis-garis istimewa. Para mahasiswa juga memiliki persepsi positif pada perangkat lunak GeoGebra berbasis ELITA dalam minat dan motivasi belajar geometri bidang. Perangkat lunak ini harus diperkenalkan kepada mahasiswa calon guru Matematika sehingga nantinya dapat menjelajahi dunia matematika secara lebih luas dan membuat mahasiswa calon guru matematika mampu berpikir kritis dan kreatif dalam pembelajaran geometri. 


\section{Ucapan Terima Kasih}

Penelitian ini dapat dilaksanakan dengan baik berkat bantuan dari berbagai pihak, untuk itu peneliti mengucapkan terima kasih kepada Direktorat Jenderal Pembelajaran dan Kemahasiswaan Kementerian Riset, Teknologi, dan Pendidikan Tinggi atas Program Bantuan Pengembangan Pembelajaran berpusat pada mahasiswa berbasis TIK Tahun 2019.

\section{Pustaka}

Alqahtani, M.M. \& Powell, A.B. (2016). Instrumental appropriation of a collaborative, dynamic-geometry environment and geometrical understanding. International Journal of Education in Mathematics, Science and Technology, 4(2), 72-83

Emaikwu, S. O., Iji, C. O., \& Abari, M. T. (2015). Effect of GeoGebra on senior secondary school students' interest and achievement in statistics in Makurdi local government area of Benue State, Nigeria. Journal of Mathematics (IOSRJM), 2(3), 14-21

Gunhan, B. C. (2014). A case study on the investigation of reasoning skills in geometry. South African Journal of Education, 34(2), 1-19

Guven, B., \& Kosa, T. (2008). The effect of dynamic geometry software on student mathematics teachers' spatial visualization skills. The Turkish Online of Educational Technology, 7(4), 100-107

Hohenwarter, M., Jarvis, D., \& Lavicza, Z. (2008). Linking geometry, algebra, and mathematics teachers: GeoGebra software and the establishment of the international GeoGebra institute. International Journal for Technology in Mathematics Education, $16(2), 83-86$

Kllogjeri, P. \& Shyti, B. (2010). Geogebra: a global platform for teaching and learning math together and using the synergy of mathematicians. International Journal Teaching and Case Studies, 2(3/4), 225-236. DOI: 10.1007/978-3-642-13166-0_95

Mahmudi, A. (2010, November 27). Membelajarkan geometri dengan program GeoGebra. Retrieved from https://eprints.uny.ac.id/10483/1/P6-Ali\%20M.pdf

Mejerek, D. (2014). Application of GeoGebra for teaching mathematics. Advances in Science and Technology Research Journal, 8(24), 51-54. DOI:10.12913/22998624/567

NCTM. (2000). Principles and standards for school mathematics. Reston, VA: National Council of Teachers of Mathematics

Saha, R.A., Ayub, A.F.M., \& Tarmizi, R.A. (2010). The effects of GeoGebra on mathematics achievement: enlightening coordinate geometry learning. Procedia Social and Behavioral Sciences 8, 686-693. DOI:10.1016/j.sbspro.2010.12.095 